\title{
Intracoronary Radiation
}

\author{
Lt Col Ajay Dheer* ${ }^{*}$ Lt Col SK Dutta ${ }^{+}$
}

\begin{abstract}
With in-stent restenosis remaining major limitation of coronary stenting and adjunctive pharmacologic therapy and re-stenting having failed to reduce the rates of in-stent restenosis, a new treatment alternative is warranted. Vascular brachytherapy - the intracoronary delivery of radiation has been proposed as one such therapy. Thus far it is an important break-through in combating re-stenosis. Todate, 5 years of clinical data has been generated and further studies are underway to perfect the technology.
\end{abstract}

MJAFI 2003; 59 : 136-139

Key Words : Coronary artery; Ionising radiation; Re-stenosis

\section{Introduction}

$\mathrm{R}$ e-narrowing of a coronary artery after dilatation (re-stenosis) is the principal limitation of Percutaneous Transluminal Coronary Angioplasty (PTCA)[1]. Re-stenosis typically affects between $25 \%$ to $45 \%$ of patients within six months after PTCA, resulting in the need for a repeat interventional procedure. Re-stenosis can be considered as an exaggeration of 'vascular healing' and 'remodelling' the probability that occurs to some degrees in all cases. Pharmacologic and mechanical adjuvants have made little impact on this refractory problem of post-PTCA re-stenosis. The field of 'Vascular Brachytherapy' is a new treatment alternative. It has shown promising results and is a team work of multiple disciplines. The catheter based procedure is performed by the interventional cardiologist, dosing is determined by medical physicist and the administration of radiation is performed by the radiation oncologist.

The effects of ionizing radiation on proliferating tissues are well known [2]. The main effect of clinical doses of ionizing radiation is to impair the reproductive integrity of cells, especially in the rapidly proliferating tissues. As a consequence of this DNA damage, the cell dies when it attempts to divide. The effect of radiation on proliferating tissues has been clinically exploited to treat a variety of benign conditions characterized by uncontrolled proliferation, including keloids, heterotopic bone formation etc.

Extensive animal studies and early clinical data have consistently shown that vascular brachytherapy can reduce post-angioplasty neointimal hyperplasia and

Table 1

Trials in intracoronary brachytherapy beta-radiation

\begin{tabular}{|c|c|c|c|c|}
\hline \multicolumn{2}{|c|}{ Acronym investigator Design } & \multirow{2}{*}{$\begin{array}{l}\text { Radiation system } \\
\text { (Schneider) hand loaded } \\
0.014 " 29 \text { mm fixed } 90 \mathrm{Y} \\
\text { source wire centering balloon } \\
\text { (segmented) with no perfusion } \\
\text { capability }\end{array}$} & \multirow{2}{*}{$\begin{array}{l}\text { Isotope and dose } \\
18 \text { Gy to surface of balloon }\end{array}$} & \multirow[b]{2}{*}{$\begin{array}{l}\text { Remarks } \\
\text { Although safety and feasibility } \\
\text { demonstrated there was no } \\
\text { clinical efficacy. Re-stenosis } \\
\text { rate of } 40 \% \text {. Subsequent analysis } \\
\text { showed that radiation dose to } \\
\text { adventitia was lower than desired }\end{array}$} \\
\hline $\begin{array}{l}\text { Geneva } \\
\text { Verin }\end{array}$ & $\begin{array}{l}\text { Open lable feasibility } \\
\text { study in } 15 \text { patients after } \\
\text { PTCA in de novo lesions }\end{array}$ & & & \\
\hline $\begin{array}{l}\text { BERT } \\
\text { King, Bonan } \\
\text { and Serruys }\end{array}$ & $\begin{array}{l}\text { Open label in } 23 \text { patients } \\
\text { in US arm }+30 \text { patients } \\
\text { in Canadian arm and } 30 \\
\text { patients in European } \\
\text { BERT trial. No control group }\end{array}$ & $\begin{array}{l}\text { (Novoste) Hydraulic manual } \\
\text { delivery of a train of } 12 \text { radio- } \\
\text { active seeds of } 90 \mathrm{Sr} / \mathrm{Y}(30 \mathrm{~mm}) \\
\text { in a non-centered } 5 \mathrm{Fr} \text { catheter } \\
\text { (The Betacath System) }\end{array}$ & $\begin{array}{l}12,14,16 \mathrm{~Gy} \text { to } 2 \mathrm{~mm} \text { from } \\
\text { the source }\end{array}$ & $\begin{array}{l}\text { Result of the combined groups } \\
\text { show a low re-stenosis rate } \\
\text { in the treated segment. }\end{array}$ \\
\hline BRIE & $\begin{array}{l}\text { European Registry } \\
\text { with Novoste system. }\end{array}$ & The Betacath system & $\begin{array}{l}12,14,16 \mathrm{~Gy} \text { to } 2 \mathrm{~mm} \text { from } \\
\text { the source. }\end{array}$ & $27 \%$ recurrence rate at 6 months \\
\hline $\begin{array}{l}\text { BETACHATH } \\
\text { Kuntz }\end{array}$ & $\begin{array}{l}\text { Multicentre randomized } \\
\text { blinded study in } 1100 \text { patients } \\
\text { after PTCA and provisional } \\
\text { stenting. }\end{array}$ & The Betacath system & $\begin{array}{l}14 \text { and } 18 \text { Gy to } 2 \mathrm{~mm} \text { from } \\
\text { balloon surface }\end{array}$ & $\begin{array}{l}\text { Enrollment started in Jul 97, } \\
25 \text { participating sites. }\end{array}$ \\
\hline $\begin{array}{l}\text { PREVENT } \\
\text { Raizner }\end{array}$ & $\begin{array}{l}\text { Multicentre, randomized, } \\
\text { blinded study in } 72 \text { patients } \\
\text { including stented lesions }\end{array}$ & $\begin{array}{l}\text { The Guidant Brachy-therapy } \\
\text { system consists of remote } \\
\text { controlled after loader, 32P } \\
\text { source Wire ( } 0.0014 ") \text { and } \\
\text { spiral centering balloon catheter }\end{array}$ & $\begin{array}{l}16,20 \text { and } 24 \text { Gy delivered } \\
\text { to a depth of } 1 \mathrm{~mm} \text { from } \\
\text { balloon vessel interface }\end{array}$ & $\begin{array}{l}\text { Results from } 72 \text { patients } \\
\text { low rates of re-stenosis in } \\
\text { target lesions }(6 \%) \text { with } \\
\text { adjacent segments included }\end{array}$ \\
\hline
\end{tabular}

*Medical Officer, Command Hospital (Southern Command), Pune - 411 040, +Classified Specialist (Medicine \& Cardiology), Base Hospital, Delhi Cantt 110010. 
Table 2

Trials in intracoronary brachytherapy gamma radiation

\begin{tabular}{|c|c|c|c|c|c|c|c|}
\hline Acronym investigator & Design & Radiation system & Isotope and dose & \multicolumn{4}{|l|}{ Remarks } \\
\hline $\begin{array}{l}\text { ARREST } \\
\text { David Faxon }\end{array}$ & $\begin{array}{l}\text { Randomzied trial } \\
\mathrm{N}=800(400+400)\end{array}$ & $\begin{array}{l}\text { Catheter based intracoronary } \\
\text { radiotherapy }\end{array}$ & 192 Ir 12 Gy @ 2 mm & \multicolumn{4}{|c|}{ Final results pending } \\
\hline $\begin{array}{l}\text { ARTISTIC } \\
\text { Ron Walks-Man, } \\
\text { Washington DC, USA }\end{array}$ & Randomized trial $\mathrm{N}=290$ & $\begin{array}{l}\text { Angiorad mechanical delivery } \\
\text { system of } 0.014 \text { " fixed wire } \\
30 \mathrm{~cm} \text { into a mono rail closed } \\
\text { end lumen Balloon centering } \\
\text { Catheter }(3.2 \mathrm{Fr})\end{array}$ & 192 Ir 12 GY @ 2 mm & \multicolumn{4}{|c|}{$\begin{array}{l}26 \text { patients completed major } \\
\text { event-3 (Death, MI, TLR, } \\
\text { CABG) PTCA to TLR-1 } \\
\text { PTCA to NON TLR-1 }\end{array}$} \\
\hline $\begin{array}{l}\text { GAMMA-1 } \\
\text { Martin B } \\
\text { Washington DC, USA }\end{array}$ & $\begin{array}{l}\text { Multicentre randomized } \\
\text { trial } \\
\mathrm{N}=252(126+126)\end{array}$ & Post PTCA IVUS guided & $\begin{array}{l}192 \text { Ir } 8-30 \text { Gy to } \\
\text { adventitia }\end{array}$ & \multicolumn{4}{|c|}{$\begin{array}{l}\text { Re-stenosis markedly reduced. } \\
\text { Re-stenosis rate shorter lesions } \\
(6,10 \text { seeds) } 15.2 \% \text { vs } 48.4 \% \\
\text { longer lesions ( } 14 \text { seeds) } 31.1 \% \\
\text { vs } 7.9 \%\end{array}$} \\
\hline GAMMA-II & $\mathrm{N}=125$ & do & 14 Gy @2 mm & \multicolumn{4}{|l|}{ Active } \\
\hline $\begin{array}{l}\text { GAMMA } \\
\text { Wire Jose A } \\
\text { Venezuela }\end{array}$ & $\begin{array}{l}\text { Prospective registry } \\
\text { adjunctive local } \\
\text { Gamma radiation }\end{array}$ & PTCA + 192 Ir & $192 \mathrm{Ir}$ & \multicolumn{4}{|c|}{$\begin{array}{l}\text { Low rate of angiographic } \\
\text { re-stenosis }\end{array}$} \\
\hline $\begin{array}{l}\text { SCRIPPS } \\
\text { Pauls S Teirstein CA }\end{array}$ & $\begin{array}{l}\text { Double blind randomized } \\
\text { trial } \mathrm{N}=55(26+29)\end{array}$ & $\begin{array}{l}\text { Catheter based intracoronary } \\
\text { radiotherapy+Stenting }\end{array}$ & 192 Ir 8-30 Gy & $\begin{array}{l}2 \text { year foll } \\
\quad \text { Ir } \\
\text { Death } \\
\text { MI } 1 \\
\text { TLR } \\
\text { Pr endpt }\end{array}$ & $\begin{array}{l}\mathrm{W} \\
\mathrm{Pa} \\
2 \\
2 \\
4 \\
6\end{array}$ & $\begin{array}{l}\text { op } \\
2 \\
\text { NS } \\
13 \\
15\end{array}$ & $\begin{array}{l}\text { NS } \\
0.01 \\
0.03\end{array}$ \\
\hline $\begin{array}{l}\text { SMARTS } \\
\text { Ron Walksman } \\
\text { Washington }\end{array}$ & $\begin{array}{l}\text { Randomized Trial } \\
\mathrm{N}+180\end{array}$ & $\begin{array}{l}\text { Balloon centering catheter } \\
\text { Mechanical delivery of } 0.014 \text {, } \\
\text { fixed wire }\end{array}$ & 192 Ir 12 Gy @ 2 mm & \multicolumn{4}{|l|}{ Active } \\
\hline $\begin{array}{l}\text { INDIRA } \\
\text { AM Nissar Syed } \\
\text { Collaboration } \\
\text { India and USA }\end{array}$ & $\begin{array}{l}\text { Prospective randomized trial } \\
\mathrm{N}=48\end{array}$ & Catheter based & $\begin{array}{l}192 \text { Ir } 11 \text { Gy to } \\
\text { adventitia }\end{array}$ & \multicolumn{4}{|l|}{ Active } \\
\hline
\end{tabular}

reduce the risk of re-stenosis [3]. A large number of different isotopes and treatment devices are currently being evaluated in over 30 clinical trials in North America, Europe and elsewhere as is given in Table 1 \& Table 2 using beta \& gamma radiation respectively [4].

The radiation system used and the findings of some trials using beta and gamma radiation sources are as under :

\section{BETA Vascular Brachytherapy - Clinical Trials}

Beta emitters known for their unique qualities of high energies and low penetration make them attractive for use in trials in vascular brachytherapy involving multiple systems and isotopes [5]. The trials using beta radiation systems are as under :

(a) RENO (European Registry Novoste Trial) - The largest consecutive registry of patients, initiated in April 1999 and clinical data currently available for 1085 patients out of total 1098 patients from 46 hospitals throughout Europe and Middle East clearly demonstrates high procedural success and low rates of both in hospital events and 6 month major adverse cardiac effect (MACE) [6].

(b) START and START 40 Trials - Strontium 90/ Yttrium 90 source delivered by Beta-Cath system - a portable system that hydraulically delivers the radiation to the coronary arteries. Interim results are shown in Table 3 [7]. The findings indicate that treating lesions with longer sources reduces the incidence of restenosis by $51 \%$. Longer source wire reduces the incidence of edge effect and geographical miss.

(c) BRITE and BETTER Trials - 32P source delivered by the RDX system - a balloon system that incorporates solid 32P into balloon material using a trilayered, sealed source designed to ensure equal dose distribution to the vessel wall. Interim results are shown in Table 4 [7]. The findings indicate that intracoronary radiation with RDX system is safe since very low TVR and MACE rates have been reported.

(d) PREVENT AND INHIBIT TRIALS - P 32 source delivered by Galileo Intravascular Radiotherapy system which utilizes a P32 source wire delivered through a helical centering balloon that allows side branch and distal perfusion. The two trials, PREVENT (Proliferation Reduction and Vascular Energy Trial) and INHIBIT (Inhibit re-stenosis with beta radiation), initiated to evaluate the use of the Galileo system for the treatment of re-stenosis.

GAMMA Vascular Brachytherapy - Clinical Trials

(a) SCRIPPS WRIST AND GAMMA Trials - They 
Table 3

Patient data from START TRIAL

Released at the $12^{\text {th }}$ Annual Transcatheter Cardiovascular Therapeutics (TCT) meeting and XXIII Congress of European Society of Cardiology

\begin{tabular}{llll}
\hline & Control & START 30 & START 40 \\
\hline Enrolled patients & 232 & 244 & 207 \\
Angiographic analysis (Interim) 188 & 198 & 137 \\
Source train (Sr 90 wire) & & $30 \mathrm{~mm}$ & $40 \mathrm{~mm}$ \\
Dose & & $16 \mathrm{~Gy} / 20 \mathrm{~Gy}$ & $16 \mathrm{~Gy} / 20 \mathrm{~Gy}$ \\
6 month follow-up & & & \\
TLR & $27.9 \%$ & & $11.4 \%$ \\
TVR & $28.8 \%$ & & $14.3 \%$ \\
MACE & $29.7 \%$ & & $16.5 \%$ \\
2 year follow-up & & & \\
TLR & $34.9 \%$ & & $22.5 \%$ \\
TVR & $37.9 \%$ & & $27 \%$ \\
MACE & $39.7 \%$ & & $30 \%$ \\
Restenosis rate (\%) & & & \\
Stent segment & $41 \%$ & $14 \%$ & $16 \%$ \\
Total analysis segment & $45 \%$ & $29 \%$ & $22 \%$ \\
\hline
\end{tabular}

START - $90 \mathrm{Sr}$ treatment of angiographic restenosis

Table 4

Patient data from BRITE and BETTER trials

Released at $12^{\text {th }}$ Annual TCT Meeting XXIII Congress of European Society of Cardiology

\begin{tabular}{lcc}
\hline & BETTER & BRITE \\
\hline Number of patients & $\mathrm{N}=82$ & $\mathrm{~N}=94$ \\
Death & $1(1.39 \%)$ & 0 \\
MI & $1(1.39 \%)$ & $1(1.1 \%)$ \\
TLR & $18(22.5 \%)$ & $10(10.6 \%)$ \\
CABG & 0 & $1(1.1 \%)$ \\
Any MACE & $20(24 \%)$ & $11(11.7 \%)$ \\
Re-stenosis & - & $8.4 \%$ \\
\hline
\end{tabular}

MI - Myocardial infarction; TLR - Target lesion revascularisation; CABG - Coronary artery bypass graft; MACE - Major adverse cardiac effects; BRITE - Beta radiation trial to reduce in-stent stenosis; BETTER - Beta radiation trial to eliminate restenosis

are all double blinded, randomized trials initiated to evaluate the safety, effectiveness, durability and simplicity of using 192Ir gamma irradiation to treat in stent re-stenosis. All the three trials have had favourable results during all points of follow-up and have demonstrated a marked reduction in the rate of re-stenosis as compared with the placebo as seen in Table 5 [7].

(b) GAMMA II Trial - A multicentre registry that compared the effects of a higher dose with the acute and long term outcomes of GAMMA I trial. The prescribed dose was $14 \mathrm{~Gy}$ at $2 \mathrm{~mm}$ from the source. Comparison is shown in Table 6 [7]. Compared with the GAMMA I trial, the results of GAMMA II suggest that higher the radiation dose, more effective the outcome. To test this theory, enrolment began recently for SCRIPPS IV trial which will use $17 \mathrm{~Gy}$ at $2 \mathrm{~mm}$ (22\% increase in dose from previous
Table 5

Data from SCRIPPS, WRIST \& GAMMA I trials

Released at $12^{\text {th }}$ Annual TCT Meeting XXIII Congress of European Soceity of Cardiology

\begin{tabular}{lccc}
\hline & SCRIPPS & WRIST & GAMMA 1 \\
\hline Number of patients & $\mathrm{N}=55$ & $\mathrm{~N}=130$ & $\mathrm{~N}=252$ \\
Dose & $8-30 \mathrm{~Gy}$ & $15 \mathrm{~Gy} @ 2 \mathrm{~mm}$ & $\begin{array}{c}8-30 \mathrm{~Gy}, \\
\text { IVUS guided }\end{array}$ \\
Follow-up & 3 years & 2 years & 1 year \\
TLR (\%) & $4(15.4 \%)$ & $21(32.3 \%)$ & $32(24.4 \%)$ \\
Total MACE & $10(38.5 \%)$ & $29(44.6 \%)$ & $37(28.2 \%)$ \\
\hline
\end{tabular}

IVUS - Intra vascular ultra sound; TLR - Target lesion revasculrisation; MACE - Major adverse cardiac effects; SCRIPPS - Scrips coronary radiation to inhibit proliferation post stenting; WRIST - Washington radiation for in-stent restenosis trial; GAMMA - Multicentre randomized trial of localized radation therapy to inhibit restenosis after stenting.

Table 6

Comparative results of GAMMA I and II

Released at $12^{\text {th }}$ Annual TCT Meeting XXIII Congress of European Soceity of Cardiology

\begin{tabular}{lccc}
\hline & Placebo & GAMMA I & GAMMA II \\
\hline Number of patients & $\mathrm{N}=121$ & $\mathrm{~N}=131$ & $\mathrm{~N}=125$ \\
TLR & $44.6 \%$ & $24.4 \%$ & $23.2 \%$ \\
MACE & $46.3 \%$ & $28.2 \%$ & $29.6 \%$ \\
Stent Closure & $1(0.8 \%)$ & $8(6.1 \%)$ & $5(4.0 \%)$ \\
@ 30-270 days & & & \\
\hline
\end{tabular}

TLR-Target lesion revascularisation; MACE-Major adverse cardiac effects

SCRIPPS studies) in 358 patients at 4 centers. The results indicate that intravascular radiation with Iridium-192 profoundly reduces in-stent re-stenosis with no apparent significant increase in the complications at three years.

Intravascular gamma radiation has also shown to improve in-stent re-stenosis in saphenous-vein bypass graft [7]. The results at 12 months of a randomized study - SVG WRIST [8] with 120 patients $(60+60)$ has shown that the re-stenosis rate in the radiation arm was $70 \%$ lower.

\section{Radioisotope Stents}

Stents which serve as an internal scaffolding, have lowered the incidence of re-stenosis in short lesions; however, the typical patient with multiple or diffuse lesions still has a significant risk of post-PTCA restenosis. Radioisotope Stents (BENESTENT and STENT Trials) have shown statistically significant reduction in angiographic and clinical re-stenosis. It combines the two technologies in one mechanism viz stent to reduce recoil and radiation to reduce intimal hyperplasia. The phase - I, Isostent for Re-stenosis Intervention Study (IRIS), a non-randomised trial with beta particle emitting stent showed promising results and was followed by IRIS - IB which has been designed to test safety of higher activity upto 1.5 micro $\mathrm{Ci}$ stents. 
Preliminary results have been encouraging and final results will have to be assessed.

\section{The Indian Experience - INDIRA Trial}

The incidence of coronary artery disease is increasing in India. Approximately 400,000 angioplasties are performed in USA each year with $<1 \%$ mortality and initial success rate of $90 \%$. However, re-stenosis occurs in 30 to $40 \%$ of these patients.

A prospective randomized trial in India [9]; Intracoronary irradiation in prevention of coronary restenosis (INDIRA), in collaboration with the Long Beach Memorial Medical Centre, Long Beach California, USA has been started in four major medical centres i.e. MediCiti Hospital, Care Hospital, Apollo Hospital and Bibi Cancer Centre.Intracoronary irradiation is delivered with Iridium-192 sources following angioplasty and stenting of the stenotic segment. The protocol requires $1100 \mathrm{cGy}$ dose to the adventitia. The study was approved by the Atomic Energy Regulatory Board (AERB) and the trial was started in December 1998 under the supervision of Dr B.C. Bhatt, Director of Radiation Protection, Bhabha Atomic Research Centre (BARC) and member of AERB. The trial is currently progressing with approximately 800 patients already enrolled and the preliminary results as indicated by the angiography have been encouraging. The experience of doing radioactive stent implantation in India is from June 98. The stent used is PS153 (Palmaz-Shatz Stent, the most commonly used stent in different trials). There is an ongoing multicenter trial with P32 stents in India (3 micro Ci) and Dr MJ Gandhi of Bombay is the principal investigator for this trial.

The associated complications of vascular brachytherapy include edge-effect (re-stenosis at the edges of target length which is believed to be due to inadequate coverage with radiation), geographical miss (missing the target length of the vessel while giving radiation) and the most problematic, late thrombosis which appears to be in the 1-3\% range. The target volume is always planned greater than the stenotic length and includes the length of the vessel with barotraumas from balloon angioplasty and stent deployment balloons. It is currently recommended to give 5-8 $\mathrm{mm}$ margin (both distal and proximal) to the traumatized area of the vessel while planning the target volume. A prolonged antiplatelet therapy (clopidogrel for 6 months) has shown to significantly decrease the late thrombosis.

\section{Other Modalities and Trials}

Besides Intracoronary Brachytherapy drug-eluting Stents [10] have entered clinical trials in combating restenosis. The preliminary data of RAVEL Trial with
Cypher device (Sirolimus-eluting stent Bx velocity) has shown $95 \%$ reduction of 1 year lumen loss due to restenosis, as measured by IVUS (Intravascular ultrasound). A second trial SIRIUS, with 1103 patients registered and randomized with 550 cases in the sirolimus arm is under progress. Some other drugs being used are Paclitaxel (ASPECT Trial), Actinomycin - D (ACTION Trial) with results expected in near future.

Intracoronary Sonotherapy is also undergoing clinical trials - Sonotherapy for In-stent Elimination of Neointimal Tissue (SILENT) and Compassionate Use Study [6], after observational and feasibility study conducted in limited number of patients showed that late lumen loss is comparable to conventional approaches in the prevention of re-stenosis.

\section{Conclusion}

The technology for Intracoronary Brachytherapy is simple and is currently the most effective treatment for in-stent restenosis. The procedure is safe, providing low environmental exposure to both patient and operator (with proper protection). There is dose dependent effect with higher doses increasing effectiveness and long term outcome. Although the findings confirm the efficacy of this modality, substantially longer follow-up will confirm whether this treatment can be sustained without long term side effects.

\section{References}

1. Teirstein PS, Masullo V, Jani S et al. Catheter based radiotherapy to inhibit restenosis after coronary stenting : N Engl J Med 1997;336:1697-1703.

2. Dattatreyudu N. Weill Medical College of Cornell University, New York; Isotope and Radiation devices in endovascular brachytherapy, 1999 Aug 14-15, International Conference on Coronary Radiotherapy, Apollo Hospital, Hyderabad, India.

3. Tripureneni P. Scripps Clinic, La Jolla, California, USA; Mechanisms of Radiation Inhibition of vascular restenosis, 1999 Aug 14-15, International Conference On Coronary Radiotherapy, Apollo Hospital, Hyderabad, India.

4. Bhargava B. Clinical Trials in vascular brachytherapy, 1999 Aug 14-15, International Conference On Coronary Radiotherapy, Apollo Hospital, Hyderabad, India.

5. Waksman R. Beta vascular brachytherapy, Clinical trials update; $12^{\text {th }}$ Annual Transcatheter Cardiovascular Therapeutics Meetings. Washington, 2000 Oct 17-22.

6. Luis G. Latest Research in Combating Re-stenosis, XXIII Congress of the European Society of Cardiology, 2001 (Sep 1-5), Stockholm, Sweden.

7. Tierstein PS. Gamma vascular brachytherapy; Clinical trials update $12^{\text {th }}$ Annual Transcathter Cardiovascular Therapeutics Meeting. Washington, 2000 Oct 17-22.

8. Ron W. Radiation Therapy improves outcome in In-stent restenosis of vein grafts. N Engl J Med 2002 (Apr 18).

9. Syed N. Indian INDIRA Trial, 1999 Aug 14-15, International Conference On Coronary Radiotherapy, Apollo Hospital, Hyderabad, India.

10. Tim F. New Data New Era with Drug Eluting Stents, American Heart Associations Scientific Sessions, 2001, Anaheim, California, USA.B 